\title{
THERMOCHEMICAL BEHAVIOR OF Eucalyptus grandis WOOD EXPOSED TO TERMITE ATTACK
}

\author{
Ezequiel Gallio ${ }^{1}$, Henrique Römer Schulz ${ }^{1}$, Laíse Guerreiro ${ }^{1}$, Nidria Dias Cruz ${ }^{1}$, Paula Zanatta ${ }^{2}$, \\ Mário Antônio Pinto da Silva Júnior, Darci Alberto Gatto ${ }^{3,4}$
}

\begin{abstract}
This study aimed to evaluate the variations in thermal and chemical characteristics of juvenile Eucalyptus grandis wood submitted to a deterioration test by Nasutitermes termites. For this purpose, a biodeterioration test with termites was conducted according to ASTM D 3345 (2008), in which, after the end of the period corresponding to the test (40 days), we evaluated the mass loss, chemical composition and thermal stability of the main components of the deteriorated wood samples and those belonging to the control group. We found that deterioration due to exposure of the samples to Nasutitermes sp. termites caused a mass loss of $66,88 \%$ for wood with a density at $12 \%$ moisture content of $412 \mathrm{~kg} / \mathrm{m}^{3}$. The quantitative chemical composition showed a reduction in the contents of cellulose, hemicellulose and lignin. Analysis of the variations of the organic functional groups related to the chemical composition of the wood by Fourier Transform Infrared Spectroscopy and relative intensity of the spectral bands also showed reductions, demonstrating homogeneous deterioration of the main components of the deteriorated woods. The thermal stability showed an increase in deteriorated wood for most of the temperature ranges, mainly for those that corresponded to losses in moisture and volatiles (25 $\left.{ }^{\circ} \mathrm{C}-100^{\circ} \mathrm{C}\right)$, hemicelluloses $\left(240^{\circ} \mathrm{C}-300^{\circ} \mathrm{C}\right)$, celluloses, and together with initial lignin degradation $\left(310^{\circ} \mathrm{C}\right.$ to $400{ }^{\circ} \mathrm{C}$ ), possibly due to the removal of cellulose and hemicellulose, as well as the deposition of substances expelled by the termites in the cell wall. From the results, we conclude that the termites do not have specificity regarding the chemical component and that the deterioration caused variations in the chemical composition of the wood, whereas the opposite was observed for thermal stability, which presented an increase in most of the temperatures ranges for the deteriorated woods compared to the control group.
\end{abstract}

Keywords: Chemical composition, Nasutitermes, thermal stability, wood deterioration, wood protection.

\section{INTRODUCTION}

In 2016, Brazil had a total of 7,84 million hectares of planted forests, of which 5,67 million were registered as Eucalyptus, 1,58 million Pinus and 0,59 million of other genres. From 2015 to 2016, only Eucalyptus presented growth of $0,5 \%$ (BTI 2017). These figures indicate that Eucalyptus species have a great potential, mainly due to their high productivity and rapid growth (Hubbard et al. 2010), thus presenting as an alternative to the use of native woods in the timber productive chain.

Due to their interesting and varied properties, this genus, mainly Eucalyptus grandis, is widely used in the paper and cellulose industries, as well as for manufacturing of furniture, railway sleepers, fence posts and construction. However, as it is a material of organic origin, like any other wood type, it is vulnerable to the attack of several biotic agents, such as termites, which are a big threat to the wood's useful lifespan. This attack is due

${ }^{1}$ Programa de Pós Graduação em Ciência e Engenharia de Materiais, Centro de Desenvolvimento Tecnológico, Universidade Federal de Pelotas, Pelotas, RS, Brasil.

${ }^{2}$ Programa de Pós-Graduação em Engenharia Florestal, Centro de Ciências Agroveterinárias, Universidade do Estado de Santa Catarina, Lages, SC, Brasil.

${ }^{3}$ Curso de Engenharia Industrial Madeireira, Centro de Engenharias, Universidade Federal de Pelotas, Pelotas, RS, Brasil.

"Corresponding author: gattodarci@gmail.com

Received: 28.11.2018 Accepted: 24.12.2019 
to the ease that these xylophagous organisms have in digesting the lignocellulosic biomass that constitutes the cell wall of the wood in order to meet their energy demands (Couturier et al. 2015).

Due to the large variety of wood species, it should be noted that the durability of this material depends on several factors: the proportion of heartwood and sapwood, the chemical composition (mainly content and composition of extractives and lignin), density, moisture content, hardness, and use conditions (Haupt et al. 2003, Brischke et al. 2014, Delucis et al. 2016).

Termite attacks on wood cause significant damages, sometimes requiring replacement, depending on the degree of deterioration. Besides the social and economic impacts, this deterioration changes the technological properties of the wood, such as chemical, physical and mechanical properties (Malakani et al. 2014), which compromises its use and durability. According to Constantino (2002), there are many species of termites in South America, several of them considered structural and agricultural pests, because of their highly destructive potential in using vegetable and wood components as food resources. The subfamily Nasutitermitinae is among those that cause most damage to wood in tropical regions (Boulogne et al. 2017). Among the known genres, the Nasutitermes includes approximately $54 \%$ of all species present in this region. They are considered different structural pests that are able to attack woods with different density classes (Constantino 2002, Stallbaun et al. 2017).

Thus, aiming to obtain information about wood durability of one of the most used and planted species in the country, the present work aimed to analyze the variations in chemical characteristics and thermal stability in spawood of Eucalyptus grandis wood resultant of the deterioration caused by termites Nasutitermes sp.

\section{MATERIAL AND METHODS}

\section{Material used}

For this study, we used specimens measuring 2,0 x 2,0 x $15 \mathrm{~cm}$ (tangential plane x radial x longitudinal, respectively) from a 12-year-old Eucalyptus grandis, collected in a forest garden near Guaíba city, Rio Grande do Sul, Brazil. Subsequently, the 30 specimens were kept in a room with controlled conditions $\left(20^{\circ} \mathrm{C}\right.$ temperature and $65 \%$ air humidity) until mass stabilization occurred (hygroscopic equilibrium of $12 \%$ ).

\section{Experimental procedure}

After the stabilization period, the density at moisture content $\left(\rho_{12 \%}\right)$ was determined using Equation 1. For that, the mass $\left(\mathrm{M}_{12 \%}\right)$ and volume $\left(\mathrm{V}_{12 \%}\right)$ of the test specimens were obtained using an analytical balance and a digital pachymeter (accuracy of $\pm 0,001 \mathrm{~mm}$ ), respectively, obtaining the volume by stereometric method.

$$
\rho_{12 \%}\left(\mathrm{~g} / \mathrm{cm}^{3}\right)=\frac{M_{12 \%}(\mathrm{~g})}{V_{12 \%}\left(\mathrm{~cm}^{3}\right)}
$$

In order to perform the biodeterioration test, 15 specimens were placed inside a microfiber box (2000 liters capacity) containing a $10 \mathrm{~cm}$ layer of sand (periodically moistened) as a substrate, under which they were partially buried (approximately $2 / 3$ of their length). The Nasutitermes termite test was conducted adapting the standard of the American Society for Testing and Materials (ASTM D 3345-74 (2008)), for a 40-day period.

Once the biodeterioration test was finalized, the specimens were removed from the exposition to the termites and carefully cleaned (substrate and termites were removed) through the use of a spatula and a brush. They were then placed back in the room under the conditions of temperature and humidity mentioned previously. 


\section{Analysis of wood deteriorated by Nasutitermes}

The deterioration caused by termites Nasutitermes sp. in the Eucalyptus grandis wood was verified by analysis of mass loss, changes in chemical properties and thermal stability. The adaptation of standard ASTM D 2017 (2005) made it possible to determine the mass loss (Equation 2), where ML is the mass loss (percentage) and, $M_{B}$ and $M_{A}$ are the masses (grams) of the samples before and after the biodeterioration test by termites, respectively.

$$
M L=\left(\frac{M_{B}-M_{A}}{M_{B}}\right) x 100
$$

Aiming to verify variances in homogeneity, the mass loss data was converted into Arcsen ( $\sqrt{\mathrm{ML}} / 100)$, as suggested by Steel and Torrie (1980). Subsequently, the test specimens of the control and deteriorated groups were milled in a Willey-type knife mill, passing through a set of sieves (40 and 60 meshs, respectively). The powder retained in the 60 mesh was used for the analysis of the deterioration caused by Nasutitermes sp. in the other properties of interest to the present study.

The thermal behavior of the wood was evaluated by thermogravimetric analysis (TGA). For this, a Netzsch TG 209F1 equipament was used with the following parameters: initial temperature of $30^{\circ} \mathrm{C}$, heating rate of 10 ${ }^{\circ} \mathrm{C} \cdot \mathrm{min}^{-1}$, final temperature of $700{ }^{\circ} \mathrm{C}$, under inert atmosphere, with nitrogen gas flow.

Regarding the chemical analysis, quantitative and qualitative chemical analyses were carried out. The quantification of the main chemical components of wood from the control group and the sample deteriorated by termites was carried out in triplicate, according to an adaptation of the methodology described by TAPPI (2007) standard and Rowell (1983), presented in Table 1.

Table 1: List of methodologies applied for the determination of the wood's chemical components.

\begin{tabular}{|c|c|}
\hline Chemical Compound & Methodology used \\
\hline Cellulose & \multirow{2}{*}{ Rowell (1983) } \\
\hline Hemicellulose & \\
\hline Extractives & TAPPI T-204 cm-97 \\
\hline Lignin & TAPPI T-222 om-98 \\
\hline
\end{tabular}

The Fourier transform Infrared Spectroscopy (FT-IR) was used for the qualitative study of the recurrent variations in the chemical composition, as a function of the termite attack. The parameter used was absorbance, regarding a total spectrum resulting from 32 readings in the spectrum range between 1800 and $600 \mathrm{~cm}^{-1}$. The spectrum was normalized using the wavelength of $1030 \mathrm{~cm}^{-1}$, as it does not subject to change when exposed to different conditions used in the material (Chen et al. 2012, Missio et al. 2015).

Aiming to facilitate an understanding of the recurrent variations in the chemical components, a complementary analysis was developed by obtaining the ratio between the relative intensities of spectra related to the lignin band $\left(1508 \mathrm{~cm}^{-1}\right)$ and carbohydrates $\left(890 \mathrm{~cm}^{-1}, 1370 \mathrm{~cm}^{-1}, 1420 \mathrm{~cm}^{-1}, 1740 \mathrm{~cm}^{-1}\right)$. The $1508 \mathrm{~cm}^{-1}$ band was used as reference, since it is considered pure, without influence of other chemical components (Pandey and Pitman 2003). 


\section{RESULTS AND DISCUSSION}

The mass loss due to deterioration caused by termites of Nasutitermes genus in Eucalyptus grandis species was of $66,88 \%$ for the wood used, with density at $12 \%$ moisture content $\left(\rho_{12 \%}\right)$ of $412 \mathrm{~kg} / \mathrm{m}^{3}$. Table 2 shows that the deterioration caused by termites resulted in reductions in contents of the cellulose, hemicellulose and lignin (main components) of the deteriorated woods compared to the control group, whereas the the inverse ocurred with the extractives. The increase in the percentage of secondary metabolites can be justified by the deterioration of the other components of the cell wall of the wood.

Table 2: Average values of chemical composition of woods of the control group and deteriorated by termites of Nasutitermes genus.

\begin{tabular}{|l|c|c|c|c|}
\hline Treatment & Cellulose (\%) & Hemicellulose (\%) & Lignin (\%) & Extractives (\%) \\
\hline Control & 53,24 & 17,58 & 22,11 & 1,11 \\
\hline Deteriorated & 50,53 & 16,31 & 20,33 & 1,66 \\
\hline
\end{tabular}

According to Watanabe and Tokuda (2010), these insects degrade the cellulose and hemicellulose present in the cell wall of the wood by means of the symbiotic association with bacteria and or protozoa residing in their digestive tracts, which release enzymes that act to break and convert main components into smaller molecules, making them available as a nutrient source for the termites. Differently, the lignin suffers with degradation mainly due to scarification process.

The relation between the wavelengths and the functional groups, the types of vibrations and the respective chemical components analyzed in this study are presented in Table 3.

Table 3: Relation between the main chemical components of wood (cellulose $=1$; hemicellulose $=2$; lignin $=3$ ) with the respective bands of the infrared spectrum.

\begin{tabular}{|c|c|c|c|}
\hline $\begin{array}{c}\text { Chemical } \\
\text { compound }\end{array}$ & Wavelenght $\left(\mathbf{c m}^{-1}\right)$ & $\begin{array}{c}\text { Functional group / Vibra- } \\
\text { tion type }\end{array}$ & Reference \\
\hline 1 & 890 & $\mathrm{C}-\mathrm{OH}$ stretching vibration; & 1 \\
\hline 1,2 and 3 & 1030 & $\begin{array}{c}\mathrm{C}-\mathrm{O} \text { stretching and C-H } \\
\text { deformation; }\end{array}$ & 2 \\
\hline 2 & 1230 & $\begin{array}{c}\text { Acetyl and carboxyl vibra- } \\
\text { tion in xylan; }\end{array}$ & 3 \\
\hline 1 and 3 & 1325 & $\begin{array}{c}\mathrm{C}-\mathrm{H} \text { vibration in cellulose } \\
\text { and }\end{array}$ & 4 \\
\hline 1 and 2 & 1368 & $\begin{array}{c}\mathrm{C}-\text { Hibration in syringyl } \\
\text { derivatives }\end{array}$ & 5 \\
\hline 1 & 1420 & $\mathrm{C}-\mathrm{H} 2$ scissor vibration; & 6 \\
\hline 3 & 1460 & $\begin{array}{c}\text { Aromatic C-H deforma- } \\
\text { tion; }\end{array}$ & 7 \\
\hline 3 & 1508 & $\begin{array}{c}\mathrm{C}=\mathrm{C} \text { stretching vibration in } \\
\text { aromatic ring }\end{array}$ & 8 \\
\hline 3 & 1590 & $\begin{array}{c}\text { Aromatic skeletal vibra- } \\
\text { tions; }\end{array}$ & 9 \\
\hline 2 & 1730 & $\mathrm{C}=\mathrm{O}$ stretching vibration; & 10 \\
\hline
\end{tabular}

${ }^{1}$ Zhang et al. (2015), ${ }^{2}$ Darwish et al. (2013), ${ }^{3}$ Yilgor et al. (2013), ${ }^{4}$ Pandey and Pitman (2003), ${ }^{5}$ Tomak et al. (2013), ${ }^{6}$ Tomak et al. (2013), ${ }^{7}$ Fackler et al. (2007), ${ }^{8}$ Darwish et al. (2013), ${ }^{9}$ Pozo et al. (2006), ${ }^{10}$ Zhang et al. (2015). 
Figure 1 shows an increase in the intensities of the spectral of wood deteriorated by termites in comparison with the control group, mainly in the bands of $1368 \mathrm{~cm}^{-1}, 1325 \mathrm{~cm}^{-1}, 1230 \mathrm{~cm}^{-1}, 1030 \mathrm{~cm}^{-1}$ and $890 \mathrm{~cm}^{-1}$. This is not indicating an increase in the quantity of the components, but rather the occurrence of a change in the chemical composition of the wood, which is associated with the degradation of cellulose, hemicellulose and lignin due to the termite attack.

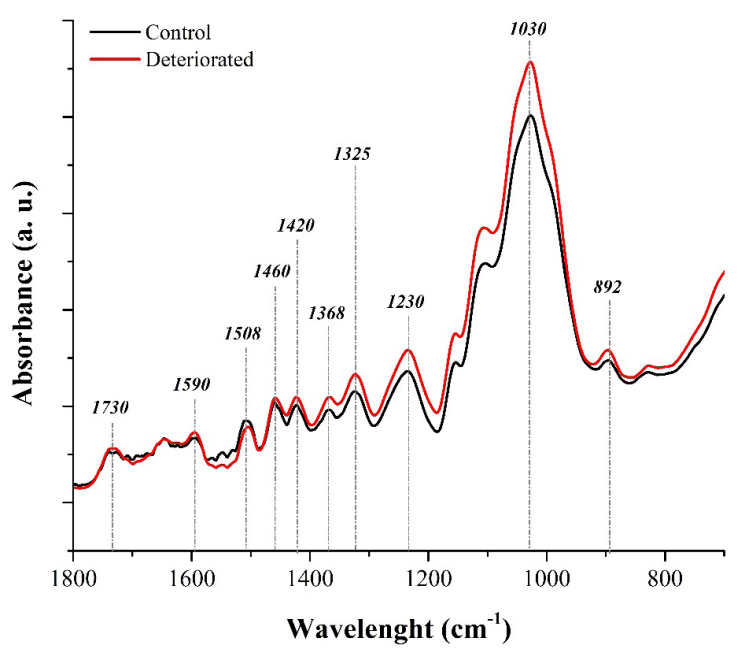

Figure 1: FTIR spectra of the woods of the control group and deteriorated by termites of Nasutitermes genus.

Zhang et al. (2015) and Yilgor et al. (2013) have argued that changes in peak intensities of spectra are caused by changes in the amounts of the chemical compounds present in the wood. Besides the deterioration of cellulose, hemicellulose and lignin, variations in intensities are associated with the appearance of new functional groups (Pandey and Pitman 2003). The increase in peaks intensities of $1368 \mathrm{~cm}^{-1}, 1325 \mathrm{~cm}^{-1}, 1230$ $\mathrm{cm}^{-1}, 1030 \mathrm{~cm}^{-1}$ and $892 \mathrm{~cm}^{-1}$ are associated with the removal of carbohydrates and increased concentration of different chemical structures of lignin (for example, guaiacil and syringyl).

Aiming to prove the variation of functional groups related to the wood's chemical composition, Table 4 presents the relative intensity values of the lignin / carbohydrate ratio.

Table 4: Relative values of the bands relating lignin (I1508) with carbohydrates (I890; I1370; I1420; I1740) from the woods of the control group and deteriorated by termites of Nasutitermes genus.

\begin{tabular}{|c|c|c|c|c|}
\hline Treatment & $\mathbf{I}_{\mathbf{1 5 0 8}} / \mathbf{I}_{\mathbf{8 9 0}}$ & $\mathbf{I}_{\mathbf{1 5 0 8}} / \mathbf{I}_{\mathbf{1 3 7 0}}$ & $\mathbf{I}_{\mathbf{1 5 0 8}} / \mathbf{I}_{\mathbf{1 4 2 0}}$ & $\mathbf{I}_{\mathbf{1 5 0 8}} / \mathbf{I}_{\mathbf{1 7 4 0}}$ \\
\hline Control & 0,627 & 0,951 & 0,859 & 0,531 \\
\hline Deteriorated & 0,586 & 0,840 & 0,803 & 0,592 \\
\hline
\end{tabular}

The decrease in the lignin / carbohydrate ratio is possibly associated to the decrease in the amount of holocellulose (cellulose and hemicellulose) in relation to lignin with a more accentuated rate of deterioration, which presented the oposite behavior in relation to the relative intensity of carbonyl $\left(\mathrm{I}_{1508} / \mathrm{I}_{1740}\right)$. This proves that the termites deteriorate the main components of wood in a similar way, and have no specificity in relation to a particular chemical component. 
Graphs A and B of Figure 2 show that the thermo-degradation for both treatments occurred in three main zones (a, b and c). The first one shows the loss mass as a function of humidity $\left(25^{\circ} \mathrm{C}\right.$ to $\left.100{ }^{\circ} \mathrm{C}\right)$ present in the wood, while the second and third zones are mainly related to the hemicelluloses and the volatiles $\left(240{ }^{\circ} \mathrm{C}\right.$ to $\left.300{ }^{\circ} \mathrm{C}\right)$ and the cellulose $\left(310^{\circ} \mathrm{C}\right.$ to $\left.400{ }^{\circ} \mathrm{C}\right)$, respectively, with lignin slowly degrading from the beginning of the thermal process.
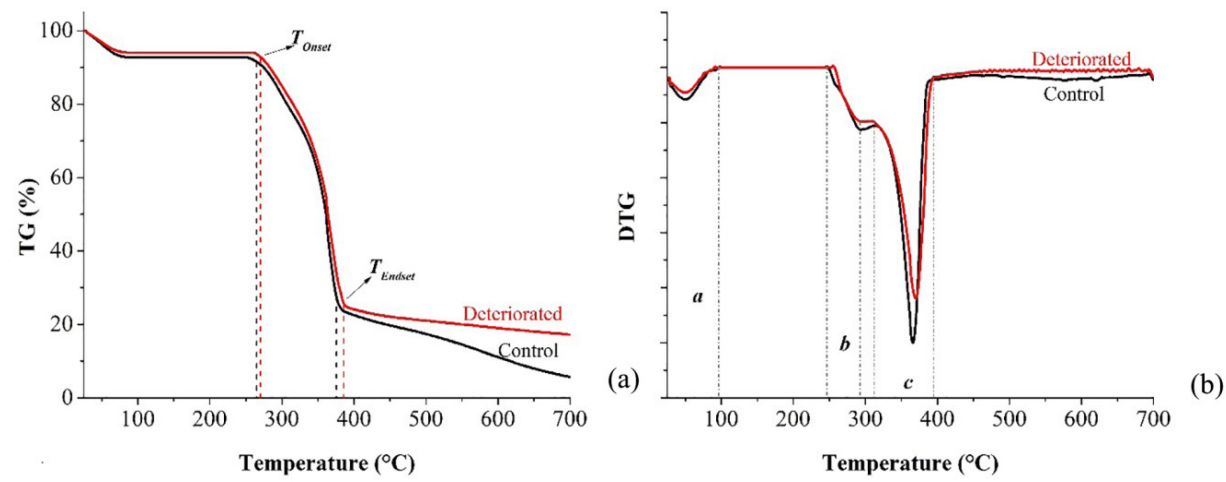

Figure 2: (a) TGA and (b) DTG curves of the woods of the control group and deteriorated by termites of Nasutitermes genus.

Extrapolating the degradation curves of the hemicelluloses and cellulose, represented by the points at the TOnset and TEndset temperatures (Figure 2a), there is a slight displacement of the deteriorated wood to a higher temperature when compared to the control.

Observing the derivative (Figure 2b), the presence of a small shoulder at approximately $290{ }^{\circ} \mathrm{C}$ is noted, characterizing the hemicelluloses. These were noticeably degraded due to the termite attack, because the shoulder of the deteriorated wood presents a reduction when compared to the control treatment.

Cellulose is characterized by having the highest peak at about $370{ }^{\circ} \mathrm{C}$. Like the hemicelluloses, there was a decrease in the intensity of the peak (mass loss) of the deteriorated wood, indicating a decrease in the amount of cellulose, as a result of termite degradation. As for lignin, the presence of a bending in the control treatment after $450{ }^{\circ} \mathrm{C}$ was observed, while the deteriorated wood remains practically constant, indicating again that the termites also degrade the lignin.

Table 5 presented the decreases of mass for the deteriorated wood in comparison to the control group in most of the temperature ranges, with the exception of the temperature range of $350-400{ }^{\circ} \mathrm{C}$, which mainly covers the cellulose and lignin. As shown, approximately $60 \%$ of the mass loss occurred in the temperature range between 300 and $400{ }^{\circ} \mathrm{C}$, as well as in the study carried out by Crespo et al. (2015) with young wood of Acacia mangium ( $80 \%$ of mass loss). 
Table 5: Percentage values of mass loss (\%) as a function of different temperature ranges for woods of the control group and deteriorated by termites of Nasutitermes genus.

\begin{tabular}{|c|c|c|}
\hline Temperature ranges $\left({ }^{\circ} \mathbf{C}\right)$ & Control & Deteriorated \\
\hline $30-100$ & 7,25 & 5,84 \\
\hline $100-150$ & 0,00 & 0,00 \\
\hline $150-200$ & 0,00 & 0,00 \\
\hline $200-250$ & 0,66 & 0,54 \\
\hline $250-300$ & 10,44 & 9,97 \\
\hline $300-350$ & 21,11 & 20,73 \\
\hline $350-400$ & 38,77 & 40,05 \\
\hline $400-450$ & 2,81 & 1,99 \\
\hline $450-500$ & 2,31 & 1,11 \\
\hline $500-550$ & 2,88 & 1,00 \\
\hline $550-600$ & 3,43 & 1,01 \\
\hline $600-650$ & 3,11 & 0,93 \\
\hline $650-700$ & 2,23 & 0,86 \\
\hline Residual mass & 4,99 & 15,97 \\
\hline
\end{tabular}

Due to the removal of cellulose and hemicellulose from the cell wall, which have a large amount of hydroxyl groups, the wood tends to decrease its moisture exchange capacity. The hemicelluloses have lower thermal stability in relation to the other components of the wood (Alfredsen et al. 2012), so the decrease in quantity of these components implies a lower mass loss as a function of the temperature. The chemical component with the highest thermal stability is cellulose (Sebio-Puñal et al. 2012). which presented similar degradation profiles for the two treatments.

In this context Gašparovič et al. (2012) observed that hemicelluloses and cellulose presented the highest degradation rates in temperatures of $290{ }^{\circ} \mathrm{C}$ and $350{ }^{\circ} \mathrm{C}$, respectively, similar to the degradation profiles observed in this study.

With regards to the lignin, the removal of this component as a function mainly of the scarification process changes the original characteristics of this component, causing variations in resistance to thermo-degradation. Therefore, the smaller mass loss corresponding to the lignin region is associated to the degradation mechanism used by the termites and the removal of this component from the interior of the wood by these xylophagus.

Regarding the residual mass at the end of the test, it was evident that the deteriorated samples had a higher percentage value when compared to the control. Aydemir et al. (2011) also observed that the degradation of the main chemical components causes an increase in the residual mass of degraded woods (Carpinus betulus and Abies bornmulleriana) subjected to thermal treatment, when compared to the control treatment.

This is also explained by the removal of the major chemical components from the wood, especially the hemicelluloses. Removal of these components from the interior of the wood may have led to a reduction in the mass loss because they are thermally unstable.

Also. considering that the amounts of these components were reduced as a function of the degradation caused by the termites, the material that was previously degraded as a function of heat (of the samples from the control group) was not present in the analysis and. for this reason, was not degraded as a function of temperature.

\section{CONCLUSIONS}

The deterioration caused by termites of the genus Nasutitermes sp. changed the chemical characteristics and thermal stability of Eucalyptus grandis wood. Based on the quantitative chemical analysis, the occurence of a non-preferential degradation of the main chemical components of the wood (cellulose, hemicellulose) was observed, proving the low specificity of this xylophagus for the component and the type of wood to be 
deteriorated.

The infrared spectroscopy technique, together with the analysis of the relative intensity of the bands of spectra and modifications of the functional groups, contributed positively to the study, since they enhanced the understanding of the recurrent variations in the chemical structure of the wood deteriorated by the termites in relation to the control group.

The application of the thermogravimetric analysis allowed to correlate the mass loss with the attack of the termites, demonstrating that there was a reduction in the mass loss of the deteriorated wood due to the termite attack, which is related to the degradation of the primary components (cellulose, hemicellulose and lignin) of the wood.

\section{ACKNOWLEDGMENTS}

This study was financed in part by the Coordenação de Aperfeiçoamento de Pessoal de Nível Superior Brasil (CAPES) - Finance Code 001.

\section{REFERENCES}

Alfredsen, G.; Bader, T.K.; Dibdiakova, J.; Filbakk, T.; Bollmus, S.; Hofstetter, K. 2012. Thermogravimetric analysis for wood decay characterization. European Journal of Wood and Wood Products 70(4): 527-530. http://dx.doi.org/10.1007/s00107-011-0566-7.

ASTM. 2008. Standard Test method for laboratory evaluation of wood and other cellulosic materials for resistance to termites. ASTM D 3345-74. 2008. West Conshohocke.

ASTM. 2005. Standard test method of accelerated laboratory test of natural decay resistance of woods. ASTM D 2017. 2005. Annual book of ASTM standards. ASTM, West Conshohocken, PA.

Aydemir, D.; Gunduz, G.; Altuntas, E.; Ertas, M.; Turgut, H.; Alma, M. H. 2011. Investigating changes in the chemical contituents and dimensional stability of heat-treated hornbeam and uludag fir wood. BioResources 6(2): 1308-1321. https://ojs.cnr.ncsu.edu/index.php/BioRes/article/view/BioRes_06_2_1308_ Ayedemir_GAESA_Changes_Chem_Phys_Wood_Heat_Treat/924.

Boulogne, I.; Constantino, R.; Amusant, N.; Falkowski, M.; Rodrigues, A.M.S.; Houël, E. 2017. Ecology of termites from the genus Nasutitermes (Termitidae: Nasutitermitinae) and potential for science-based development of sustainable pest management programs. Journal of Pest Science 90(1): 19-37. https://doi. org/10.1007/s10340-016-0796-x.

Brazilian Tree Industry. BTI. 2017. Annual Report: base year 2016. 2017. 80 f. Brasília and São Paulo, Brazil. https://iba.org/images/shared/Biblioteca/IBA_RelatorioAnual2017.pdf.

Brischke, C.; Meyer, L.; Olberding, S. 2014. Durability of wood exposed in ground e comparative field trials with different soil substrates. International Biodeterioration \& Biodegradation 86(Part B): 108-114. https://doi.org/10.1016/j.ibiod.2013.06.022.

Chen, Y.; Fan, Y.; Gao, J.; Stark, N. M. 2012. The effect of heat treatment on the chemical and color change of black locust (Robinia pseudoacacia) wood flour. BioResources 7(1):1157-1170. https://ojs.cnr.ncsu. edu/index.php/BioRes/article/view/BioRes_07_1_1157_Chen_FGS_Heat_Treat_Chem_Color_Wood.

Constantino, R. 2002. The pest termites of South America: taxonomy, distribution and status. Journal of Applied Entomology 126: 355-365. https://doi.org/10.1046/j.1439-0418.2002.00670.x.

Couturier, M.; Navarro, D.; Chevret, D.; Henrissat, B.; Piumi, F.; Ruiz-Dueñas, F. J.; Martinez, A.T.; Grigoriev, I.V.; Riley, R.; Lipzen, A.; Berrin, J.; Master, E.R.; Rosso, M. 2015. Enhanced degrada- 
tion of softwood versus hardwood by the white-rot fungus Pycnoporus coccineus. Biotechnology for Biofuels 8(216):16 p. https://doi.org/10.1186/s13068-015-0407-8.

Crespo, Y.A.; Naranjo, R.A.; Burgos, J.C.V.; Sanchez, C.G.; Sanchez, E.M.S. 2015. Thermogravimetric analysis of thermal and kinetic behavior of Acacia mangium wood. Wood and Fiber Science 47(4): 327-335. https://wfs.swst.org/index.php/wfs/article/view/2363.

Darwish, S.S.; El Hadidi, N.M.N.; Mansour, M. 2013.The effect of fungal decay on Ficus sycomorus wood. International Journal of Conservation Science 4(3): 271-282. https://scholar.cu.edu.eg/?q=nesrin/files/ ijcs-13-26-darwish.pdf.

Delucis, R.A.; Cademartori, P.H.G.; Missio, A.L.; Gatto, D.A. 2016. Decay resistance of four fast-growing eucalypts wood exposed to three types of fields. Maderas. Ciencia y Tecnología 18(1): 33-42. https://doi. org/10.4067/S0718-221X2016005000004.

Fackler, K.; Schwanninger, M.; Gradinger, C.; Hinterstoisser, B.; Messner, K. 2007. Qualitative and quantitative changes of beech wood degraded by wood-rotting basidiomycetes monitored by Fourier transform infrared spectroscopic methods and multivariate data analysis. FEMS Microbiol Lett 271(2): 162-169. https:// doi.org/10.1111/j.1574-6968.2007.00712.x.

Gašparovič, L.; Labovský, J.; Markoš, J.; Jelemenský, L. 2012. Calculation of kinetic parameters of the thermal decomposition of wood by distributed activation energy model (DAEM). Chemical and Biochemical Engineering Quarterly 26(1): 45-53. https://hrcak.srce.hr/79392.

Haupt, M.; Leithoff, H.; Meier, D.; Puls, J.; Richter, H. G.; Faix, O. 2003. Heartwood extractives and natural durability of plantation-grown teakwood (Tectona grandis L.) - A case study. Holz als Roh- und Werkstoff 61(6): 473-474. https://doi.org/10.1007/s00107-003-0428-z.

Hubbard, R.M.; Stape, J.; Ryan, M.G.; Almeida, A.C.; Rojas, J. 2010. Effects of irrigation on water use and water use efficiency in two fast growing Eucalyptus plantations. Forest Ecology and Management 259(9): 1714-1721. https://doi.org/10.1016/j.foreco.2009.10.028.

Malakani, M.; Khademieslam, H.; Hosseinihashemi, S.K.; Zeinaly, F. 2014. Influence of fungal decay on chemi-mechanical properties of beech wood (Fagus orientalis). Cellulose Chemistry and Technology 48(12): 97-103. http://www.cellulosechemtechnol.ro/pdf/CCT1-2(2014)/p.97-103.pdf.

Missio, A.L.; Mattos, B.D.; Cademartori, P.H.G.; Pertuzzatti, A.; Conte, B.; Gatto, D. A. 2015. Thermochemical and physical properties of two fast-growing eucalypt woods subjected to two-step freeze-heat treatments. Thermochimica Acta 615: 15-22. https://doi.org/10.1016/j.tca.2015.07.005.

Pandey, K.K.; Pitman, A.J. 2003. FTIR studies of the changes in wood chemistry following decay by brown-rot and white-rot fungi. International Biodeterioration \& Biodegradation 52: 151-160. https://doi. org/10.1016/S0964-8305(03)00052-0.

Pozo, C.; Díaz-Visurraga, J.; Contreras, D.; Freer, J.; Rodríguez, J. 2006. Characterization of temporal biodegradation of radiata pine by Gloeophyllum trabeum through principal component analysis-based two-dimensional correlation FTIR spectroscopy. Journal of the Chilean Chemical Society 61(2): 2878-2883. http://dx.doi.org/10.4067/S0717-97072016000200006.

Rowell, R. 1983. The Chemistry of Solid Wood. In: Proceedings of a symposium at the 185 th meeting of the American Chemical Society. Seattle, Washington, March 20-25: 70-72.

Sebio-Puñal, T.; Naya, S.; López-Beceiro, J.; Tarrío-Saavedra, J.; Artiaga, R. 2012. Thermogravimetric analysis of wood, holocellulose, and lignin from five wood species. Journal of Thermal Analysis and Calorimetry 109(3): 1163-1167. https://doi.org/10.1007/s10973-011-2133-1.

Stallbaun, P.H.; Barauna, E.E.P.; Paes, J.P.; Ribeiro, J.B.; Ribeiro, N.C.; Monteiro, T. C.; Arantes, M.D.C. 2017. Natural resistance of Sclerolobium paniculatum Vogel wood to termites in laboratory conditions. Floresta e Ambiente 24: e-20160013. http://dx.doi.org/10.1590/2179-8087.001316.

Steel, R.G.D.; Torrie, J.H. 1980. Principles and procedures of statistic: a biometrical approach. 2. ed. 
New York: McGrawHill. 633 p.

Tomak, E.D.; Topalogu, E.; Gumuskaya, E.; Yildiz, U.C.; Ay, N. 2013. An FT-IR study of the changes in chemical composition of bamboo degraded by brown-rot fungi. International Biodeterioration \& Biodegradation 85: 131-138. https://doi.org/10.1016/j.ibiod.2013.05.029.

Watanabe, H.; Tokuda, G. 2010. Cellulolytic systems in insects. Annual Review of Entomology 55: 609632. https://doi.org/10.1146/annurev-ento-112408-085319.

Yilgor, N.; Dogu, D.; Moore, R.; Terzi, E.; Kartal, S.N. 2013. Evaluation of fungal deterioration in Liquidambar orientalis Mill. heartwood by FT-IR and light microscopy. BioResources 8(2): 2805-2826. https:// doi.org/10.15376/biores.8.2.2805-2826.

Zhang, X.; Wang, F.; Keer, L.M. 2015. Influence of surface modification on the microstructure and thermo-mechanical properties of bamboo fibers. Materials 8(10): 6597-6608. https://doi.org/10.3390/ma8105327. 